Published in final edited form as:

Acta Physiol (Oxf). 2015 July ; 214(3): 303-310. doi:10.1111/apha.12508.

\title{
Adenosine 2A Receptors in Acute Kidney Injury
}

\author{
Isaah S. Vincent and Mark D. Okusa \\ Division of Nephrology and Center for Immunity, Inflammation and Regenerative Medicine, \\ University of Virginia Health System, Charlottesville, Virginia, USA
}

\section{Abstract}

Acute kidney injury (AKI) is an important clinical problem that may lead to death and for those who survive, the sequelae of AKI include loss of quality of life, chronic kidney disease (CKD) and end stage renal disease (ESRD). The incidence of AKI continues to rise without clear successes in humans for the pharmacological prevention of AKI or treatment of established AKI. Dendritic cells and macrophages are critical early initiators of innate immunity in the kidney and orchestrate inflammation subsequent to ischemiareperfusion injury (IRI). These innate cells are the most abundant leukocytes present in the kidney, and they represent a heterogeneous population of cells that are capable of responding to cues from the microenvironment derived from pathogens or endogenous inflammatory mediators such as cytokines or anti-inflammatory mediators such as adenosine. Lymphocyte subsets such as NKT cells and Tregs also play roles in regulating ischemic injury by promoting and suppressing inflammation, respectively.

Adenosine, produced in response to IR, is generally considered as a protective signalling molecule and elicits its physiological responses through four distinct adenosine receptors. However, its short half-life, lack of specificity, and rapid metabolism limits the use of adenosine as a therapeutic agent. These adenosine receptors play various roles in regulating the activity of the aforementioned hematopoietic cells in elevated levels of adenosine such as during hypoxia. This review focuses on the importance of one receptor, the adenosine 2 a subtype, in blocking inflammation associated with AKI.

\section{Keywords}

Adenosine; acute renal failure; inflammation; dendritic cells; macrophages

\section{Introduction}

Acute kidney injury may result from sepsis, exposure to nephrotoxic drugs, or ischemia during surgery, such as cardiopulmonary bypass. Ischemic acute tubular necrosis is the most common cause of AKI and the mechanisms involved have been well summarized by Bonventre and Yang(Bonventre and Yang, 2011). Microvascular endothelial injury is an early event that leads to endothelial activation, expression of adhesion molecules,

Correspondence to Mark D. Okusa, MD, Division of Nephrology, Box 800133, University of Virginia Health System, Charlottesville, VA 22908, USA. Tel: +1 434924 2187; fax: +1 434924 5848; mdo7y@ virginia.edu.

Conflict of Interest:

Mark Okusa has equity in Adenosine Therapeutics, LLC. 
vasoconstriction, and leukocyte adhesion resulting in microvascular congestion and increase in vascular permeability. The kidney mononuclear phagocytes present in the interstitial compartment (Soos et al., 2006, Li et al., 2008, Kaissling and Le Hir, 1994) respond to danger-associated molecular patterns (DAMPS) or pathogen-associated molecular patterns (PAMPS)(Rosin and Okusa, 2011) released from damaged cells or exogenous invading organisms, respectively. They also respond to molecules expressed by resident or infiltrating immune cells including lymphocytes, natural killer T cells (NKT cells), epithelial cells, and fibroblasts. In the presence of PAMPS or DAMPS, dendritic cells (DCs) and other mononuclear phagocytes activate innate immunity in kidney ischemia-reperfusion injury (IRI). DCs contribute to the early antigen-independent inflammatory response following reperfusion, including the production of cytokines/chemokines that drive neutrophil infiltration via activation of NKT cells and the IL-17/IL-23 signaling pathway(Li et al., 2010, Li et al., 2008). In contrast, DCs can also induce tolerance by inadequate positive or enhanced negative co-stimulatory signals and reduced pro-inflammatory cytokines and can generate immune tolerance by inducing $\mathrm{T}$ cell anergy or deletion or regulatory $\mathrm{T}$ (Treg) cell induction or expansion(Morelli and Thomson, 2007, Hu and Wan, 2011, Gilboa, 2007).

We examined the role of DCs in IRI using transgenic mice expressing the human diphtheria toxin receptor [(DTR); human heparin-binding epidermal growth factor-like growth factor] in CD11 ${ }^{+}$cells (CD11c-DTR mouse)(Buch et al., 2005). Using diphtheria toxin (DT), we

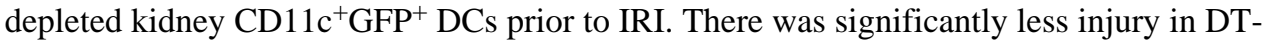
treated CD11c-DTR/GFP mice compared to CD11c-DTR/GFP mice treated with a catalytically inactive mutant DT (mDT)(Li and Okusa, 2010) strongly supporting the concept that DCs contribute to the early innate response in IRI. DC ablation in DTR mice increased injury in cisplatin-induced nephrotoxicity indicating the importance of dendritic DCs for tissue protection in a different model of kidney injury(Tadagavadi and Reeves, 2010). Thus these studies reveal disparate roles of tissue resident DCs in AKI. We hypothesize that the interstitial environment created by different pathogenic circumstances, such as cisplatin toxicity or IRI, or endogenous molecules (e.g., PAMPS, DAMPS, cytokines, autocoids such as adenosine) may govern DC function (Figure 1).

\section{Renal interstitial microenvironment}

The kidney has regenerative capacity and a unique immunological microenvironment. A detailed histological description of the renal interstitial compartment shows that it is situated between basement membranes of epithelial cells and blood vessels and contains interstitial fibroblasts and dendritic cells (Kaissling and Le Hir, 2008). The resident DCs belong to the mononuclear phagocyte system and express MHC class II and CD11c. Adenosine is a purine nucleoside that is produced by tissue under metabolic stress, such as ischemia, hypoxia, and inflammation. In the kidney, adenosine is an important regulator of metabolic cellular activity(Hansen and Schnermann, 2003). Adenosine increases to more than 6-fold normal concentrations $(<1 \mu \mathrm{M})$ following two minutes of ischemia. Once released into the interstitial microenvironment adenosine can bind to different subtypes of adenosine receptors (i.e., adenosine A1, A2A, A2b, A3Rs) expressed on various innate immune cells such as neutrophils, macrophages, DCs, natural killer cells(Fredholm et al., 2001) and modulate cellular responses(Li and Okusa, 2010, Lappas et al., 2006, Gessi et al., 2000). T 
cells express A2A, A2B, and A3 receptors ((Ehrentraut et al. 2012; Koshiba et al. 1999; Mirabet et al. 1999) and B cells have been shown to express A1, A2A and A3 receptors (Saze et al. 2013).

\section{Adenosine generation in the tissue microenvironment}

The level of adenosine within a tissue acts as an indicator of tissue oxygenation. Adenosine is generated by the breakdown of the nucleotides AMP, ADP, and ATP. Extracellularly, adenosine has a relatively short half-life (seconds) (Moser et al., 1989), and increases in adenosine concentration within the tissue microenvironment is dependent on a multitude of factors that affect both its generation and destruction. In uninflamed and normoxic conditions, the adenosine concentration within normal tissues is 50-fold less than the ATP concentration but in metabolically active or ischemic tissues, intracellular levels adenosine increase 100-fold (Hagberg et al., 1987).

Tissues with low-partial pressures of oxygen are particularly sensitive ischemia and generation of adenosine. The kidney is one such organ due to the low basal partial pressure of oxygen $\left(\mathrm{pO}_{2}\right)$ which in rats has been recorded to be $\sim 42 \mathrm{~mm} \mathrm{Hg}$ in the outer cortex and 20-30 mm Hg in the deeper cortex (Welch et al., 2001). Within the normoxic rat kidney, the levels of adenosine within the cortex $(55 \mathrm{nM})$ are far lower than the levels within the renal medulla (212 nM)(Zou et al., 1999). Perturbations of renal blood flow or $\mathrm{pO}_{2}$ exhaust ATP supplies and lead to increases in the level of adenosine(Vallon et al., 2006). This may be due to the proximal tubules constraint to oxidative phosphorylation to regenerate ATP; it is estimated that only $1-3 \%$ of ATP in the proximal tubule is generated by anaerobic glycolysis(Blantz and Weir, 2004). Thus the low $\mathrm{pO}_{2}$ of the kidney leaves it primed for generation of adenosine during episodes of ischemia or metabolic stress.

A summary of adenosine metabolism is shown in Figure 2. Inside the cell, AMP is processed into adenosine via cytosolic 5'-nucleotidases. Generation of extracellular adenosine occurs via ecto-nucleosidase CD39, which dephosphyorlates ATP to produce ADP, and ecto-5'-nucleotidase CD73, which removes the final phosphate from AMP. CD73 which is highly expressed on interstitial fibroblasts and on epithelial cells, is a cell surface enzyme that is involved in the final step in the sequential dephosphorylation of extracellular ATP(Kumar and Sharma, 2009). Accumulation of extracellular adenosine is regulated both by bi-directional and concentrative nucleoside transporters. Equilibrative nucleoside transporters (ENT) 1, 2, and 4 allow the diffusion of adenosine into and out of the cell. In isolated kidney tubule epithelial cells, the concentrative nucleoside transporters (CNTs) are predominantly expressed on the apical surface and likely to aide in adenosine reabsorption from the renal filtrate(Lai et al., 2002). In normoxic conditions, the balance between ENTs and CNTs favor the CNTs and leads to the accumulation of adenosine in the intracellular space. However, it has been demonstrated in IRI in rats that both ENT1 and 2 are suppressed after ischemia, favoring the accumulation of extracellular adenosine(Grenz et al., 2012). Thus hypoxia disrupts the transportation and leads to the accumulation of extracellular adenosine.

Acta Physiol (Oxf). Author manuscript; available in PMC 2016 July 01. 
Elevation of extracellular adenosine occurs due to the phosphohydrolysis of adenosine nucleoside precursors. ATP can be actively excreted by a variety of mechanisms, such as by voltage-gated ATP channels, or can increase due to cell injury. Sheer stress or inflammatory stimulation of endothelial cells induces their excretion of ATP(Bodin and Burnstock, 1996, Taylor et al., 1998, Bodin and Burnstock, 2001). Cell death can also lead to the liberation of intracellular pools of ATP, with both cytolytic lysis and apoptosis leading to increases in the level of extracellular ATP(Chekeni et al., 2010, Henney, 1973, Iyer et al., 2009), and subsequently to increased extracellular adenosine by metabolism of its precursors.

Adenosine is removed by metabolism to inosine by intracellular and extracellular adenosine deaminase (ADA) or back into AMP by intracellular adenosine kinase (AK). In a kidney fibroblast cell line AK predominated over ADA for removal of adenosine (Huber et al., 2001).

\section{A2AR expression in Renal Protection}

Extracellular adenosine binds to one of four G-coupled protein receptors. These receptors vary in their G-protein coupling, signaling mechanisms and tissue expression. The A1R and A3R subtypes inhibit adenylate cyclase and activate phospholipase C (Jacobson and Gao, 2006). The A2AR and A2BR subtypes activate adenylate cyclase to increase cAMP, which inhibits the activation of many immune cells. The A1R and A2AR are high affinity adenosine receptors, while A2BR and A3R have 100-fold lower affinity for adenosine than the A1R(Jacobson, 1998). In this review, we will focus primarily on the A2AR and its role in controlling inflammation after renal IRI. The role of other adenosine receptors is outlined by HT Lee in another manuscript in this series as well as previously (Lee and Emala, 2001, Yap and Lee, 2012) Initial investigations in our laboratory demonstrated the renal protective effect of A2AR agonists during IRI(Okusa et al., 1999). The A2AR is expressed on both renal and hematopoietic cells. In mice, A2AR mRNA expression is detected throughout the kidney (inner medulla>outer medulla>cortex) with strong expression in the glomerulus but not in other segments of the nephron(Vitzthum et al., 2004). These results suggest that there is additional expression of A2AR in non-epithelial cells. Given the abundance of DCs and other mononuclear phagocytes in the kidney cortex and medulla, the A2AR transcripts expressed in kidney are likely derived from resident or infiltrating hematopoietic cells. Functional data from IRI studies support this hypothesis. Infusion of selective A2AR agonists prior to IRI protects mice from injury in a receptor- dependent manner(Okusa et al., 1999), as the effect is blocked by A2AR antagonists and is absent in A2aR KO mice (Day et al., 2003, Okusa et al., 1999). To demonstrate the relative importance of hematopoietic vs. non hematopoietic A2ARs we generated bone marrow chimeras and found that A2AR agonist administration is protective only in mice bearing A2AR wild-type bone marrow and therefore that stimulation of A2AR on hematopoietic cells is necessary to protect the kidney from IRI(Day et al., 2003).

\section{A2AR regulation of Myeloid Populations}

There are multiple populations of hematopoietic cells that reside within the kidney.

Macrophages and dendritic cells (DCs) make up the largest populations of immune cells within the interstitium of the uninjured kidney. DCs are myeloid cells that mostly specialize 
in antigen-presentation to cells of the adaptive immune system. There are three main DC subsets: conventional (cDCs) and monocyte derived DCs, which both are efficient at antigen-presentation, and plasmacytoid DC, which produce type 1 interferon upon activation (an excellent recent review on DC subsets and their functions can be found here (Mildner and Jung, 2014)). In humans, kidneys contain plasmacytoid DCs and two types of conventional DCs(Woltman et al., 2007). Murine studies using GFP-labeled CX3CR1, which is a marker for DCs, demonstrate an expansive network of interstitial DCs throughout the kidney. The DCs respond to PAMPS and DAMPS, undergo activation, and can readily present antigen. Upon activation, they stimulate the activation of $\mathrm{T}$ cells, including natural killer T cells (NKT cells). F4/80 ${ }^{+}$monocytes, which are also found in the interstitium, reside predominately within the medulla but also extend throughout the kidney and interact with cortical distal and proximal tubules as well as Bowman's capsule(Hume and Gordon, 1983, Nelson et al., 2011). The monocytes and DCs form networks of cells that both respond to and modulate the renal inflammatory environment after injury.

Whilst these monocytes and DC monitor the interstitial space within the kidney, extracellular adenosine can modulate their phenotype and function, thereby altering the innate response to renal IRI. Both populations express all four adenosine receptor subtypes but unactivated macrophages and DC express A1R, A2AR and A3R(Panther et al., 2001). Activation of macrophages and DCs upregulates A2AR mRNA expression(Murphree et al., 2005, Panther et al., 2001, Sitkovsky et al., 2004). However, work in our laboratory has demonstrated that the expression of the A2AR on macrophages is not required for the kidney protective effect of A2AR agonists(Day et al., 2005).

We have examined the impact of A2AR signaling on the function of CD11c+ dendritic cells in kidney protection from IRI. We have found that subthreshold levels of ischemia, which alone did not induce injury in WT mice, induce severe injury in mice with selective deletion of A2ARs on CD11c+ DCs (Li et al., 2012). Treatment of DCs with A2AR agonists induced a tolerogenic phenotype with decreased ability to activate NKT cells in vivo. Adoptive transfer of A2AR agonist-treated DCs rendered recipient mice and their resident NKT cells unresponsive to IRI up to 7 days later, indicating that treated DCs induce a lasting anergic phenotype in NKT cells( $\mathrm{Li}$ et al., 2012). This may be due to the myriad of ways A2AR signaling modulates many facets of DC function. Early work has demonstrated that A2AR stimulation blocks DC response to several inflammatory chemokines, inhibiting DC migration along a chemokine gradient(Panther et al., 2001, Panther et al., 2003, Hofer et al., 2003), and A2AR stimulated DCs promote skewing of CD4 T cells towards a Th2 phenotype(Panther et al., 2003). With CD8 T cells, adenosine mimetic-treated DCs lead to an anergic phenotype(Challier et al., 2013). Our work demonstrate another mechanism by which A2AR regulate DC capacity to prime inflammatory immune responses.

\section{NK T cells in IRI}

NKT cell activation also plays a critical role in IRI. Early work in our lab demonstrated that a CD4+ T cell subset, later determined to be NKT cells, was activated after IRI. NKT cells respond to glycolipids presented by the non-classical MHC class II molecule CD1d. Blockade of CD1d to prevent NKT cell activation or genetic deletion of CD1d to block NKT 
cell development results in a decrease in injury after IRI(Li et al., 2007). Activation of NKT cells leads to increased immune cell infiltration of the kidney and the activation of IFN- $\gamma$ production in a population of GR1+CD11b+ neutrophils. This pro-inflammatory, AKIpromoting effect of NKT cells may be due to only a subset of invariant NKT (iNKT) cells. Yang et al. found that while CD1d-/- mice have exacerbated injury after IRI, as we have demonstrated, treatment of mice with sulfatide, which activates non-invariant NKT cells, is renal protective(Yang et al., 2011, Arrenberg et al., 2011). This apparently conflicting finding may be due to cross-regulation of iNKT cells by non-iNKT cells. Activation of noniNKT cells with sulfatide has been shown to suppress the activation of iNKT cells and prevent iNKT cell-induced injury(Arrenberg et al., 2011, Jahng et al., 2004); sulfatide can also compete directly with other molecules presented by CD1d, blocking those molecules from inducing NKT cell activation(Kanamori et al., 2012). Thus both NKT cell populations play a role in IRI and strategies to selectively activate or inhibit these populations should be sought in future therapies for protection from IRI.

A2AR signaling within NKT cells may also play a role in controlling renal IRI. Previous work in collaboration with Linden demonstrated that A2AR activation on NKT cells protects the liver from ischemic damage(Lappas et al., 2006). While depletion of NKT cells leads to a decrease in hepatic injury following hepatic ischemia, reconstitution with WT or A2AR KO NKT cells restored damage. In this model, A2AR agonists blocked hepatic IRI in mice reconstituted with WT NKT cells but failed to block injury in A2AR KO NKT cell recipients. It is still unknown which subpopulation of NKT cells plays a role in mediating injury. Further research is needed into the applicability of A2AR agonist treatment in controlling NKT cell activation in renal IRI as well as better defining which subsets of NKT cells are susceptible to inhibition by A2AR agonists.

\section{Adenosine and Tregs in IRI}

CD4+ regulatory T cells (Tregs) are another important player in controlling the extent of injury after renal IRI. Early work in our lab demonstrated that renal IRI is exacerbated in mice that have been depleted of CD4+CD25+ Tregs(Kinsey et al., 2009). In this work, when RAG1 KO mice, which lack T and B cells, were reconstituted with lymph node cells containing conventional and regulatory $\mathrm{T}$ cells, they exhibited conventional levels of kidney injury after renal IRI. However, reconstitution with lymph node cells lacking Tregs exacerbated renal injury. Injury also occurred when RAG1 KO mice were reconstituted with lymph node cells from IL-10 KO mice, indicating the renal protective effect of Tregs is due to their ability to produce IL-10(Kinsey et al., 2009).

Tregs can suppress immune activation in a myriad of ways, and generation of adenosine has recently been identified as an additional mechanism. Tregs, which express high levels of CD73 and CD39, actively produce adenosine(Borsellino et al., 2007). CD39-deficient Tregs are unable to block $\mathrm{T}$ cell proliferation(Deaglio et al., 2007). Treg-generated adenosine has a protective function, as adoptive transfer of WT but not CD73-deficient Tregs protect recipient mice from kidney IRI(Kinsey et al., 2012). Adoptively transferred WT Tregs can suppress IRI in both WT and A2AR KO recipients, but transfer of A2AR KO Tregs fails to prevent renal IRI(Kinsey et al., 2012). These results indicate that A2AR expression on the 
transferred Tregs but not on recipient cells are essential for Treg control of immune function and that Treg-generated adenosine acts in an autocrine fashion on Treg A2ARs. This autocrine loop regulates expression of the T cell regulatory protein PD-1 on Tregs; blocking PD-1 prevented the protective effect of WT Tregs in renal injury (Kinsey et al., 2012).

In summary, extracellular adenosine is an important regulator of immune cell activation in renal ischemia. Signaling through A2AR, adenosine modulates innate immune cells to prevent inflammation. By regulating DC phenotype or the suppressive capacity of regulatory $\mathrm{T}$ cells, adenosine and its receptors provide a potential therapeutic target for prevention and treatment of renal IRI.

\section{Acknowledgements}

This work was supported by National Institutes of Health grants R01 DK062324 and R01 DK085259. Isaah Vincent is a postdoctoral trainee supported by NIH 5T32DK072922.

\section{References}

Arrenberg P, Maricic I, Kumar V. Sulfatide-mediated activation of type II natural killer T cells prevents hepatic ischemic reperfusion injury in mice. Gastroenterology. 2011; 140:646-55. [PubMed: 20950612]

Blantz RC, Weir MR. Are the oxygen costs of kidney function highly regulated? Curr Opin Nephrol Hypertens. 2004; 13:67-71. [PubMed: 15090862]

Bodin P, Burnstock G. ATP-stimulated release of ATP by human endothelial cells. J Cardiovasc Pharmacol. 1996; 27:872-5. [PubMed: 8761855]

Bodin P, Burnstock G. Evidence that release of adenosine triphosphate from endothelial cells during increased shear stress is vesicular. J Cardiovasc Pharmacol. 2001; 38:900-8. [PubMed: 11707694]

Bonventre JV, Yang L. Cellular pathophysiology of ischemic acute kidney injury. J Clin Invest. 2011; 121:4210-21. [PubMed: 22045571]

Borsellino G, Kleinewietfeld M, Di Mitri D, Sternjak A, Diamantini A, Giometto R, Hopner S, Centonze D, Bernardi G, Dell'Acqua ML, Rossini PM, Battistini L, Rotzschke O, Falk K. Expression of ectonucleotidase CD39 by Foxp3+ Treg cells: hydrolysis of extracellular ATP and immune suppression. Blood. 2007; 110:1225-32. [PubMed: 17449799]

Buch T, Heppner FL, Tertilt C, Heinen TJ, Kremer M, Wunderlich FT, Jung S, Waisman A. A Creinducible diphtheria toxin receptor mediates cell lineage ablation after toxin administration. Nat Methods. 2005; 2:419-26. [PubMed: 15908920]

Challier J, Bruniquel D, Sewell AK, Laugel B. Adenosine and cAMP signalling skew human dendritic cell differentiation towards a tolerogenic phenotype with defective CD8(+) T-cell priming capacity. Immunology. 2013; 138:402-10. [PubMed: 23278551]

Chekeni FB, Elliott MR, Sandilos JK, Walk SF, Kinchen JM, Lazarowski ER, Armstrong AJ, Penuela S, Laird DW, Salvesen GS, Isakson BE, Bayliss DA, Ravichandran KS. Pannexin 1 channels mediate 'find-me' signal release and membrane permeability during apoptosis. Nature. 2010; 467:863-7. [PubMed: 20944749]

Day Y-J, Huang L, McDuffie MJ, Rosin DL, Ye H, Chen JF, Schwarzschild MA, Fink JS, Linden J, Okusa MD. Renal protection from ischemia mediated by A2A adenosine receptors on bone marrow-derived cells. J Clin Invest. 2003; 112:883-91. [PubMed: 12975473]

Day YJ, Huang L, Ye H, Linden J, Okusa MD. Renal ischemia-reperfusion injury and adenosine 2A receptor-mediated tissue protection: role of macrophages. Am J Physiol Renal Physiol. 2005; 288:F722-31. [PubMed: 15561971]

Deaglio S, Dwyer KM, Gao W, Friedman D, Usheva A, Erat A, Chen JF, Enjyoji K, Linden J, Oukka M, Kuchroo VK, Strom TB, Robson SC. Adenosine generation catalyzed by CD39 and CD73 expressed on regulatory T cells mediates immune suppression. J Ex Med. 2007; 204:1257-65. 
Fredholm BB, AP IJ, Jacobson KA, Klotz KN, Linden J. International Union of Pharmacology. XXV. Nomenclature and classification of adenosine receptors. Pharmacol Rev. 2001; 53:527-52. [PubMed: 11734617]

Gessi S, Varani K, Merighi S, Ongini E, Borea PA. A2A-adenosine receptors in human peripheral blood cells. Br.J.Pharmacol. 2000; 129:2-11. [PubMed: 10694196]

Gilboa E. DC-based cancer vaccines. J Clin Invest. 2007; 117:1195-203. [PubMed: 17476349]

Grenz A, Bauerle JD, Dalton JH, Ridyard D, Badulak A, Tak E, McNamee EN, Clambey E, Moldovan R, Reyes G, Klawitter J, Ambler K, Magee K, Christians U, Brodsky KS, Ravid K, et al. Equilibrative nucleoside transporter 1 (ENT1) regulates postischemic blood flow during acute kidney injury in mice. J Clin Invest. 2012; 122:693-710. [PubMed: 22269324]

Hagberg H, Andersson P, Lacarewicz J, Jacobson I, Butcher S, Sandberg M. Extracellular adenosine, inosine, hypoxanthine, and xanthine in relation to tissue nucleotides and purines in rat striatum during transient ischemia. J Neurochem. 1987; 49:227-31. [PubMed: 3585332]

Hansen PB, Schnermann J. Vasoconstrictor and vasodilator effects of adenosine in the kidney. Am J Physiol Renal Physiol. 2003; 285:F590-9. [PubMed: 12954591]

Henney CS. Studies on the mechanism of lymphocyte-mediated cytolysis. II. The use of various target cell markers to study cytolytic events. J Immunol. 1973; 110:73-84. [PubMed: 4631074]

Hofer S, Ivarsson L, Stoitzner P, Auffinger M, Rainer C, Romani N, Heufler C. Adenosine slows migration of dendritic cells but does not affect other aspects of dendritic cell maturation. J Invest Dermatol. 2003; 121:300-7. [PubMed: 12880422]

$\mathrm{Hu}$ J, Wan Y. Tolerogenic dendritic cells and their potential applications. Immunology. 2011; 132:307-14. [PubMed: 21208205]

Huber A, Padrun V, Deglon N, Aebischer P, Mohler H, Boison D. Grafts of adenosine-releasing cells suppress seizures in kindling epilepsy. Proc Natl Acad Sci U S A. 2001; 98:7611-6. [PubMed: 11404469]

Hume DA, Gordon S. Mononuclear phagocyte system of the mouse defined by immunohistochemical localization of antigen F4/80. Identification of resident macrophages in renal medullary and cortical interstitium and the juxtaglomerular complex. J Exp Med. 1983; 157:1704-9. [PubMed: 6854206]

Iyer SS, Pulskens WP, Sadler JJ, Butter LM, Teske GJ, Ulland TK, Eisenbarth SC, Florquin S, Flavell RA, Leemans JC, Sutterwala FS. Necrotic cells trigger a sterile inflammatory response through the Nlrp3 inflammasome. Proc Natl Acad Sci U S A. 2009; 106:20388-93. [PubMed: 19918053]

Jacobson KA. Adenosine A3 receptors: novel ligands and paradoxical effects. Trends Pharmacol Sci. 1998; 19:184-91. [PubMed: 9652191]

Jacobson KA, Gao ZG. Adenosine receptors as therapeutic targets. Nat Rev Drug Discov. 2006; 5:247-64. [PubMed: 16518376]

Jahng A, Maricic I, Aguilera C, Cardell S, Halder RC, Kumar V. Prevention of autoimmunity by targeting a distinct, noninvariant CD1d-reactive T cell population reactive to sulfatide. J Exp Med. 2004; 199:947-57. [PubMed: 15051763]

Kaissling B, Le Hir M. Characterization and distribution of interstitial cell types in the renal cortex of rats. Kidney Int. 1994; 45:709-20. [PubMed: 8196273]

Kaissling B, Le Hir M. The renal cortical interstitium: morphological and functional aspects. Histochem Cell Biol. 2008; 130:247-62. [PubMed: 18575881]

Kanamori M, Tasumi Y, Iyoda T, Ushida M, Inaba K. Sulfatide inhibits alpha-galactosylceramide presentation by dendritic cells. Int Immunol. 2012; 24:129-36. [PubMed: 22247226]

Kinsey GR, Huang L, Jaworska K, Khutsishvili K, Becker DA, Ye H, Lobo PI, Okusa MD. Autocrine adenosine signaling promotes regulatory $\mathrm{T}$ cell-mediated renal protection. J Am Soc Nephrol. 2012; 23:1528-37. [PubMed: 22835488]

Kinsey GR, Sharma R, Huang L, Li L, Vergis AL, Ye H, Ju ST, Okusa MD. Regulatory T Cells Suppress Innate Immunity in Kidney Ischemia-Reperfusion Injury. J Am Soc Nephrol. 2009; 20:1744-1753. [PubMed: 19497969]

Kumar V, Sharma A. Adenosine: an endogenous modulator of innate immune system with therapeutic potential. Eur J Pharmacol. 2009; 616:7-15. [PubMed: 19464286] 
Lai Y, Bakken AH, Unadkat JD. Simultaneous expression of hCNT1-CFP and hENT1-YFP in MadinDarby canine kidney cells. Localization and vectorial transport studies. J Biol Chem. 2002; 277:37711-7. [PubMed: 12097333]

Lappas CM, Day YJ, Marshall MA, Engelhard VH, Linden J. Adenosine A2A receptor activation reduces hepatic ischemia reperfusion injury by inhibiting CD1d-dependent NKT cell activation. J Exp Med. 2006; 203:2639-48. [PubMed: 17088433]

Lee HT, Emala CW. Systemic adenosine given after ischemia protects renal function via A(2a) adenosine receptor activation. Am J Kidney Dis. 2001; 38:610-8. [PubMed: 11532695]

Li L, Huang L, Sung SJ, Lobo PI, Brown MG, Gregg RK, Engelhard VH, Okusa MD. NKT cell activation mediates neutrophil IFN-gamma production and renal ischemia-reperfusion injury. J. Immunol. 2007; 178:5899-911. [PubMed: 17442974]

Li L, Huang L, Sung SS, Vergis AL, Rosin DL, Rose CE Jr. Lobo PI, Okusa MD. The chemokine receptors CCR2 and CX3CR1 mediate monocyte/macrophage trafficking in kidney ischemiareperfusion injury. Kidney Int. 2008; 74:1509-1511. [PubMed: 19034300]

Li L, Huang L, Vergis AL, Ye H, Bajwa A, Narayan V, Strieter RM, Rosin DL, Okusa MD. IL-17 produced by neutrophils regulates IFN-gamma-mediated neutrophil migration in mouse kidney ischemia-reperfusion injury. J Clin Invest. 2010; 120:331-42. [PubMed: 20038794]

Li L, Huang L, Ye H, Song SP, Bajwa A, Lee SJ, Moser EK, Jaworska K, Kinsey GR, Day YJ, Linden J, Lobo PI, Rosin DL, Okusa MD. Dendritic cells tolerized with adenosine A(2)AR agonist attenuate acute kidney injury. J Clin Invest. 2012; 122:3931-42. [PubMed: 23093781]

Li L, Okusa MD. Macrophages, dendritic cells, and kidney ischemia-reperfusion injury. Semin Nephrol. 2010; 30:268-77. [PubMed: 20620671]

Mildner A, Jung S. Development and function of dendritic cell subsets. Immunity. 2014; 40:642-56. [PubMed: 24837101]

Morelli AE, Thomson AW. Tolerogenic dendritic cells and the quest for transplant tolerance. Nat Rev Immunol. 2007; 7:610-21. [PubMed: 17627284]

Moser GH, Schrader J, Deussen A. Turnover of adenosine in plasma of human and dog blood. Am J Physiol. 1989; 256:C799-806. [PubMed: 2539728]

Murphree LJ, Sullivan GW, Marshall MA, Linden J. Lipopolysaccharide rapidly modifies adenosine receptor transcripts in murine and human macrophages: role of NF-kappaB in $\mathrm{A}(2 \mathrm{~A})$ adenosine receptor induction. Biochem J. 2005; 391:575-80. [PubMed: 16022683]

Nelson PJ, Rees AJ, Griffin MD, Hughes J, Kurts C, Duffield J. The Renal Mononuclear Phagocytic System. J Am Soc Nephrol. 2011

Okusa MD, Linden J, Macdonald T, Huang L. Selective A2A-adenosine receptor activation during reperfusion reduces ischemia-reperfusion injury in rat kidney. Am.J.Physiol. 1999; 277:F404F412. [PubMed: 10484524]

Panther E, Corinti S, Idzko M, Herouy Y, Napp M, la Sala A, Girolomoni G, Norgauer J. Adenosine affects expression of membrane molecules, cytokine and chemokine release, and the T-cell stimulatory capacity of human dendritic cells. Blood. 2003; 101:3985-90. [PubMed: 12446452]

Panther E, Idzko M, Herouy Y, Rheinen H, Gebicke-Haerter PJ, Mrowietz U, Dichmann S, Norgauer J. Expression and function of adenosine receptors in human dendritic cells. FASEB J. 2001; 15:1963-70. [PubMed: 11532976]

Rosin DL, Okusa MD. Dangers within: DAMP responses to damage and cell death in kidney disease. J Am Soc Nephrol. 2011; 22:416-25. [PubMed: 21335516]

Sitkovsky MV, Lukashev D, Apasov S, Kojima H, Koshiba M, Caldwell C, Ohta A, Thiel M. Physiological control of immune response and inflammatory tissue damage by hypoxia-inducible factors and adenosine A2A receptors. Annu Rev Immunol. 2004; 22:657-82. [PubMed: 15032592]

Soos TJ, Sims TN, Barisoni L, Lin K, Littman DR, Dustin ML, Nelson PJ. CX3CR1+ interstitial dendritic cells form a contiguous network throughout the entire kidney. Kidney Int. 2006; 70:5916. [PubMed: 16760907]

Tadagavadi RK, Reeves WB. Renal dendritic cells ameliorate nephrotoxic acute kidney injury. J Am Soc Nephrol. 2010; 21:53-63. [PubMed: 19875815] 
Taylor AL, Kudlow BA, Marrs KL, Gruenert DC, Guggino WB, Schwiebert EM. Bioluminescence detection of ATP release mechanisms in epithelia. Am J Physiol. 1998; 275:C1391-406. [PubMed: 9814989]

Vallon V, Muhlbauer B, Osswald H. Adenosine and kidney function. Physiol Rev. 2006; 86:901-40. [PubMed: 16816141]

Vitzthum H, Weiss B, Bachleitner W, Kramer BK, Kurtz A. Gene expression of adenosine receptors along the nephron. Kidney Int. 2004; 65:1180-90. [PubMed: 15086457]

Welch WJ, Baumgartl H, Lubbers D, Wilcox CS. Nephron pO2 and renal oxygen usage in the hypertensive rat kidney. Kidney Int. 2001; 59:230-7. [PubMed: 11135075]

Woltman AM, de Fijter JW, Zuidwijk K, Vlug AG, Bajema IM, van der Kooij SW, van Ham V, van Kooten C. Quantification of dendritic cell subsets in human renal tissue under normal and pathological conditions. Kidney Int. 2007; 71:1001-8. [PubMed: 17361115]

Yang SH, Lee JP, Jang HR, Cha RH, Han SS, Jeon US, Kim DK, Song J, Lee DS, Kim YS. Sulfatidereactive natural killer T cells abrogate ischemia-reperfusion injury. J Am Soc Nephrol. 2011; 22:1305-14. [PubMed: 21617126]

Yap SC, Lee HT. Adenosine and protection from acute kidney injury. Curr Opin Nephrol Hypertens. 2012; 21:24-32. [PubMed: 22080856]

Zou A-P, Nithipatikom K, Li P-L, Cowley AW J. Role of renal medullary adenosine in the control of blood flow and sodium excretion. Am J Physiol. 1999; 276:R790. [PubMed: 10070140] 


\section{Dendritic Cell Microenvironment}

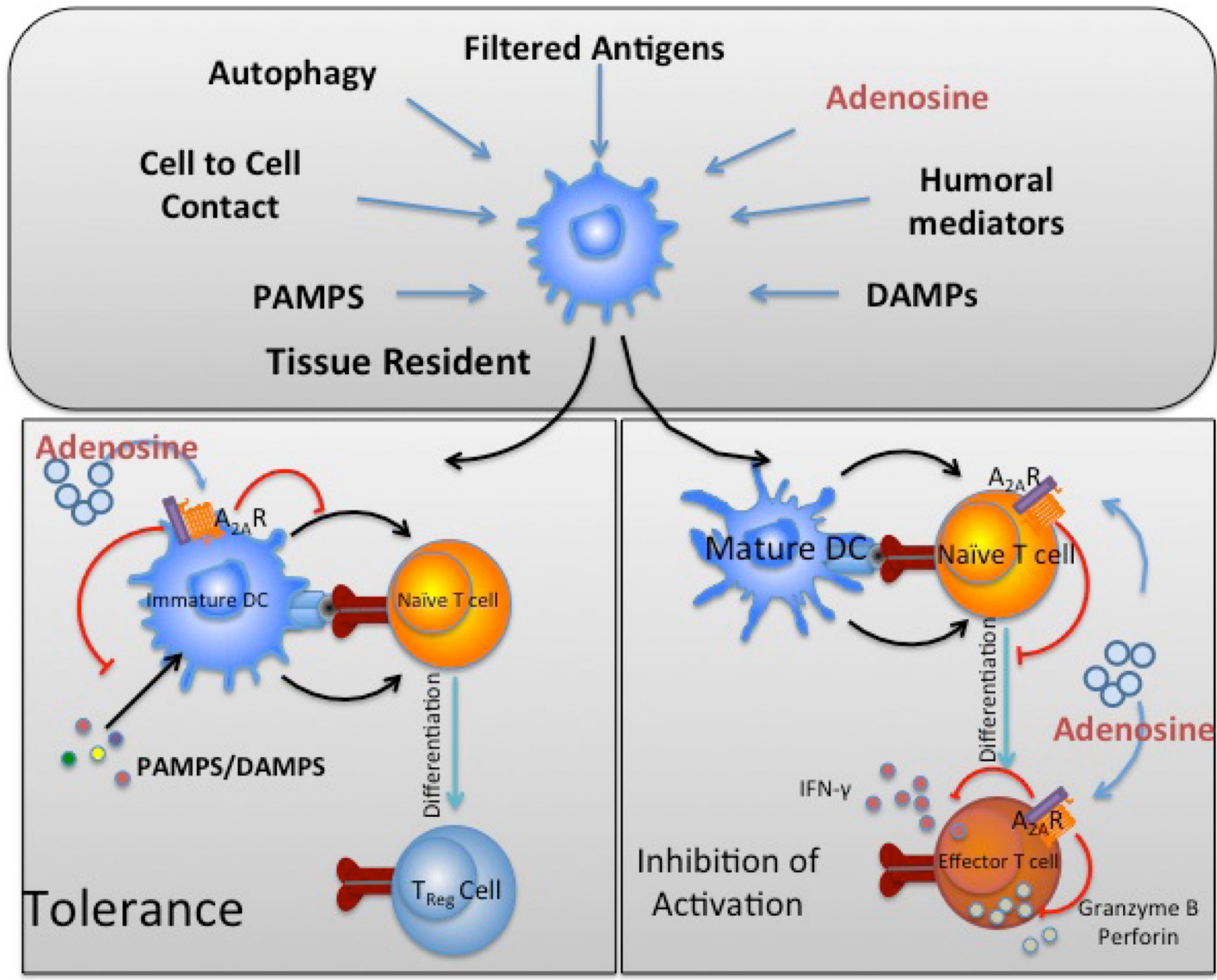

Figure 1. Dendritic cell microenvironment

Dendritic cells (DCs) reside in the kidney interstitium and respond to a number of different factors. Under normal homeostatic conditions, the immature DC engulfs proteins and other debris from surround dying cells. In the absence of inflammatory signals these immature DC expressing low amounts of costimulatory molecules and induce tolerance. During an infection, or inflammation, immature DC may induce immunity. 


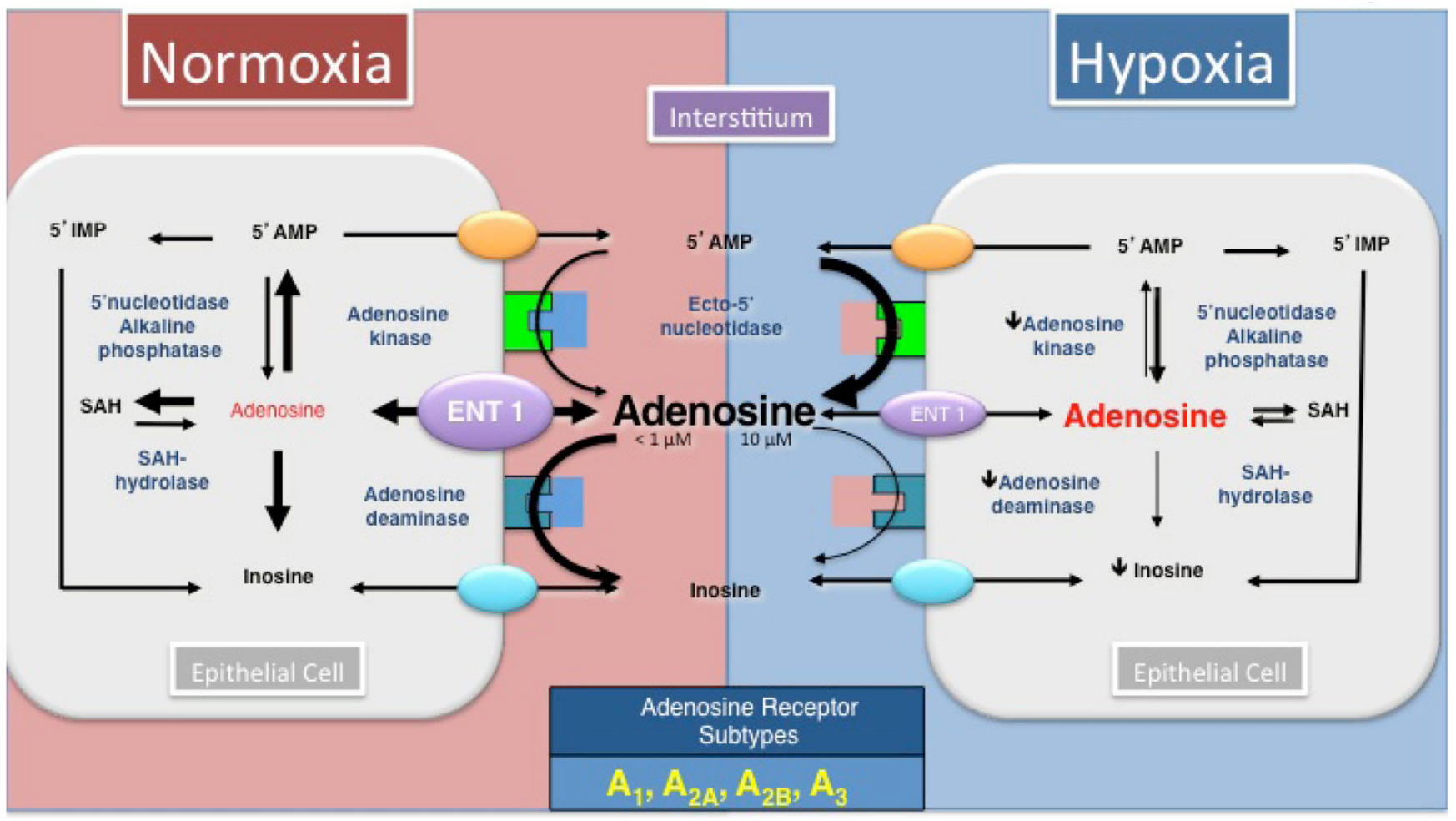

Figure 2. Adenosine Metabolism

The control of extracellular adenosine is shown. In normoxic conditions, adenosine is quickly removed via the actions of nucleotidases, adenosine kinase, and adenosine deaminase. During hypoxia, several key components of adenosine generation/degradation are regulated, leading to the overall increase in extracellular adenosine. $5^{\prime}$ IMP, inosine monophosphate; 5'AMP, 5' adenosine monophosphate; SAH-hydrolase, S-adenosyl-Lhomocysteine hydrolase; ENT1, equilibrative nucleoside transporter 1. 